\title{
Kemampuan Pemecahan Masalah Matematis Siswa SMP pada Materi Bangun Ruang
}

\author{
Harry Dwi Putra ${ }^{1 *}$, Nazmy Fathia Thahiram ${ }^{2}$, Mentari Ganiati ${ }^{3}$, Dede Nuryana ${ }^{4}$ \\ 1,2,3,4 Program Studi Pendidikan Matematika, IKIP Siliwangi, Jl Terusan Jenderal Sudirman Cimahi \\ 40526, Indonesia \\ e-mail: harrydp.mpd@gmail.com, telp +6282218208662
}

\section{Article received :30 Desember 2017, article revised :, 14 Januari 2018 article published: 01 Maret 2018}

\begin{abstract}
Abstrak
Penelitian ini bertujuan untuk menganalisis kemampuan pemecahan masalah matematis siswa dalam menyelesaikan soal bangun ruang dan mengetahui pendapat siswa terhadap matematika. Penelitian dilakukan pada siswa kelas VII di salah satu SMPN di Cimahi. Pendekatan penelitian yang digunakan adalah kualitatif dengan metode deskriptif. Instrumen terdiri dari soal pemecahan masalah, pedoman wawancara, dan angket yang sudah dilakukan validasi. Tes yang dikerjakan siswa diberi skor dan dilakukan analisis terhadap kesalahan jawaban. Angket digunakan untuk memperoleh informasi tentang pendapat siswa dalam menyelesaikan masalah. Hasil penelitian menunjukkan bahwa sebanyak 5 siswa melakukan kesalahan pemahaman, sebanyak 13 siswa melakukan kesalahan transformasi, sebanyak 29 siswa melakukan kesalahan keterampilan, dan sebanyak 33 siswa melakukan kesalahan penyimpulan, sehingga dapat dinyatakan bahwa kemampuan pemecahan masalah siswa pada salah satu SMPN di Cimahi masih rendah sehingga perlu dilakukan upaya peningkatan. Namun, siswa memiliki pendapat yang positif terhadap matematika dengan rata-rata $69,41 \%$.
\end{abstract}

Kata Kunci : Kemampuan Pemecahan Masalah Matematis, Pendapat Siswa

\section{Mathematical Problem Solving Ability of Junior High School Students on the Subject Matter of Three-Dimentional}

\begin{abstract}
This study aims to analyze students 'mathematical problem-solving abilities in solving the problem of waking space and knowing students' opinions on mathematics. The study was conducted on grade VII students at one of SMPN in Cimahi. The research approach used is qualitative with descriptive method. Instruments have been validated and consist of problem-solving test, interview guides, and questionnaires. The test that students do is given a score and an analysis of error answers. Questionnaires are used to obtain information about students' opinions in solving problems. The results showed that as many as 5 students made comprehensions error, as many as 13 students made transformation error, as many as 29 students made process skill error, and as many as 33 students made encoding error, so it can be concluded that the problem-solving ability of students in one of SMPN in Cimahi is still low so it is necessary to do improvement effort. However, students have a positive opinion on mathematics with an average of $69.41 \%$.
\end{abstract}

Keywords : Mathematical Problem Solving Ability, Student Opinion 


\section{PENDAHULUAN}

Pada umumnya setiap individu tidak terlepas dari berbagai macam masalah, baik masalah yang berhubungan dengan matematika maupun masalah kehidupan sehari-hari. Dalam pelajaran matematika siswa sering menghadapi masalah berupa soal yang berkaitan dengan materi. Siswa kesulitan dalam memecahkan masalah tersebut karena kurang terbiasa mengerjakan soal kemampuan pemecahan masalah (Windari, Dwina, \& Suherman, 2014). Kondisi ini menyebabkan rendahnya kemampuan pemecahan masalah siswa (Mawaddah \& Anisah, 2015; Widodo \& Kartikasari, 2017).

Siswa terkadang merasa malas memecahkan masalah disebabkan kurangnya pengetahuan yang mereka miliki untuk menyelesaikannya. Berdasarkan temuan Putra (2014) pada salah satu sekolah menengah di Bandung Barat dari 35 hanya siswa dalam satu kelas hanya $14,29 \%$ siswa yang sudah berada pada tahap berpikir formal (abstrak). Kondisi ini menyebabkan sebagian besar siswa belum dapat memahami konsep matematika yang abstrak apalagi untuk diterapkan dalam penyelesaian masalah.

Menurut Hadi \& Radiyatul (2014) dan Nurianti, Halini, \& Ijudin (2015) bahwa siswa cenderung menghafal rumus tanpa memahami konsep dan mengerjakan masalah matematika dengan ceroboh. Siswa lebih senang menggunakan cara yang singkat tanpa memperhatikan proses penyelesaian dengan benar. Suasana pembelajaran juga mempengaruhi kemampuan pemecahan masalah siswa. Menurut pendapat Ulvah (2016) siswa yang terlibat aktif dalam proses pembelajaran memiliki kemampuan pemecahan masalah yang lebih baik daripada siswa yang tidak terlibat dalam pembelajaran. Melalui aktivitas pembelajaran yang baik, siswa tidak akan jenuh belajar sehingga kemampuan pemecahan masalah mereka dapat berkembang.

Pemecahan masalah matematis merupakan salah satu kemampuan dasar yang harus dikuasai siswa karena dianggap sebagai jantungnya matematika (Branca, 1980). Melalui pemecahan masalah diharapkan siswa dapat menemukan konsep matematika yang dipelajari (Hendriana \& Sumarmo, 2014). Apabila siswa dapat menemukan konsep berarti mereka dapat memahami penggunaan konsep tersebut dalam menyelesaikan masalah. Menurut Winarni \& Harmini (2015) salah satu tujuan belajar matematika itu adalah untuk melatih kemampuan pemecahan masalah siswa.

Polya (1973) mengemukakan langkahlangkah pemecahan masalah matematis yaitu memahami masalah, menentukan rencana stra- tegi pemecahan masalah, menyelesaikan masalah, dan memeriksa kembali jawaban. Melalui langkah-langkah ini diharapkan siswa dapat menyelesaikan permasalahan matematika yang dihadapi. Namun, masih banyak siswa yang melakukan kesalahan ketika mengerjakan soal matematika. Newman (1977) mengklasifikasi jenis-jenis kesalahan yang dilakukan siswa dalam menyelesaikan soal pemecahan masalah, yaitu kesalahan membaca (reading error), kesalahan pemahaman (comprehension error), kesalahan transformasi (transformation error), kesalahan keterampilan proses (process skill error), dan kesalahan penyimpulan (encoding error).

Newman (1977) menjelaskan bahwa kesalahan membaca terjadi ketika siswa tidak dapat memahami kata kunci atau simbol yang terdapat dalam masalah, kesalahan pemahaman terjadi ketika siswa mampu membaca informasi pada masalah tetapi tidak dapat memahami maksud dari pertanyaan, kesalahan transformasi terjadi ketika siswa telah memahami masalah tetapi tidak dapat mengidentifikasi strategi yang diperlukan untuk menyelesaikan masalah, kesalahan keterampilan proses terjadi ketika siswa sudah dapat mengidentifikasi strategi yang digunakan tetapi tidak memahami cara menggunakan strategi tersebut, kesalahan penyimpulan terjadi ketika siswa tidak dapat mengidentifikasi masalah dan mengumpulkan semua informasi untuk menyelesaikan masalah.

Penelitian ini bertujuan untuk menganalisis kesalahan siswa SMP dalam menye- 
lesaikan soal pemecahan masalah matematis dilihat dari tahap pemahaman, transformasi, keterampilan proses, dan penyimpulan. Masingmasing tahapan saling berkaitan satu sama lain.

\section{METODE}

Penelitian ini menggunakan pendekatan kualitatif dengan metode deskriptif untuk memperoleh gambaran tentang kemampuan pemecahan masalah matematis siswa. Subjek penelitian ini adalah siswa kelas VII pada salah satu SMPN di Cimahi yang terdiri dari 36 siswa. Instrumen penelitian yang digunakan terdiri dari tes pemecahan masalah, pedoman wawancara, dan angket yang sudah dilakukan validasi.

Teknik analisis data dilakukan melalui tiga tahap yaitu memeriksa hasil jawaban siswa, menyajikan data tes dan angket siswa, serta menarik kesimpulan dari hasil penelitian. Untuk mengetahui persentase setiap jenis kesalahan jawaban digunakan rumus:

Keterangan:

$$
P=\frac{n}{N} \times 100 \%
$$

$\mathrm{P}$ : Presentasi jenis kesalahan

$N$ : Banyak kesalahan untuk masingmasing jenis kesalahan.

\section{HASIL DAN PEMBAHASAN}

Tes yang diujikan berkenaan dengan materi bangun ruang. Jawaban siswa dianalisis melalui empat tahap, yaitu pemahaman, transformasi, keterampilan proses, dan penyimpulan. Keempat tahap ini saling berkaitan antara satu dengan yang lain. Apabila siswa dapat mengerjakan tahap pertama, siswa akan dapat melanjutkan mengerjakan tahap kedua, ketiga, dan keempat. Berikut ini dijelaskan mengenai tahapan yang akan dilakukan siswa dalam menyelesaikan soal pemecahan masalah.

1. Tahap pemahaman. Tahap ini bertujuan untuk mengetahui kemampuan siswa dalam memahami masalah ketika merubah informasi pada soal ke dalam model matematika untuk menentukan nilai $x$.
Berdasarkan penilaian diperoleh data banyak siswa yang menjawab benar pada tahap pemahaman adalah $85,29 \%$ dan sisanya menjawab salah.

2. Tahap transformasi. Tahap ini bertujuan untuk mengetahui kemampuan siswa dalam mensubstitusikan nilai $x$ ke persamaan matematika untuk menentukan nilai panjang dan lebar. Berdasarkan penilaian diperoleh data banyak siswa yang menjawab benar pada tahap transformasi adalah $61,76 \%$ dan sisanya menjawab salah.

3. Tahap keterampilan proses. Tahap ini bertujuan untuk mengetahui kemampuan siswa dalam mencari tinggi balok dengan mengkonstruksi gambar balok terlebih dahulu. Informasi yang diketahui pada soal adalah panjang diagonal ruang sehingga untuk memperoleh tinggi balok siswa menggunakan teorema Pythagoras. Berdasarkan penilaian diperoleh data banyak siswa yang menjawab benar pada tahap keterampilan proses adalah $14,71 \%$ dan sisanya menjawab salah.

4. Tahap penyimpulan. Tahap ini bertujuan untuk mengetahui kemampuan siswa dalam mengidentifikasi masalah, mengumpulkan semua informasi, dan menyimpulkan solusi dari masalah. Siswa diharapkan dapat menentukan volume balok dari informasi yang diperoleh pada tahap pertama, kedua, dan ketiga. Berdasarkan penilaian diperoleh data banyak siswa yang menjawab benar pada tahap penyimpulan adalah $2,94 \%$ dan sisanya menjawab salah.

Pada Tabel 1 berikut ini ditampilkan data banyak siswa yang menjawab soal pemecahan masalah dengan benar dan salah.

Tabel 1. Persentase Jawaban Siswa pada Soal Pemecahan Masalah

\begin{tabular}{lcccc}
\hline \multicolumn{1}{c}{ Tahap } & Benar & $\%$ & Salah & $\%$ \\
\hline Pemahaman & 29 & 85,29 & 5 & 14,71 \\
Transformasi & 21 & 61,76 & 13 & 38,24 \\
Keterampilan & 5 & 14,71 & 29 & 85,29 \\
Proses & & & & \\
Penyimpulan & 1 & 2,94 & 33 & 97,06 \\
\hline \multicolumn{1}{c}{ Persentase } & $41,18 \%$ & \multicolumn{5}{c}{$58,82 \%$} \\
\hline
\end{tabular}


Tabel 1 menunjukkan bahwa dari 34 siswa hanya satu orang yang dapat menjawab soal pemecahan masalah yang diberikan. Siswa yang menjawab salah pada keempat aspek lebih banyak daripada siswa yang menjawab benar yaitu sebesar $58,82 \%$ siswa melakukan kesalahan dalam menyelesaikan soal pemecahan masalah. Siswa banyak melakukan kesalahan dalam menjawab soal pada aspek penyimpulan yaitu sebesar 97,06\% diikuti kesalahan pada aspek kete-rampilan proses, transformasi, dan pemahaman.

Siswa banyak menjawab benar pada aspek pemahaman sebesar $85,29 \%$ kemudian diikuti aspek transformasi, keterampilan proses, dan penyimpulan. Kondisi ini menunjukkan bahwa tahapan penyelesaian soal saling berkaitan dan semakin sukar untuk diselesaikan. Siswa dapat menyelesaikan masalah apabila mereka dapat memahami pertanyaan, melakukan transformasi konsep, memiliki keterampilan dalam menerapkan konsep, dan menyimpulkan hasil yang diperoleh dengan benar.

Berikut ini soal pemecahan masalah yang diberikan pada siswa:

Diketahui sebuah balok dengan tinggi $x \mathrm{~cm}$, panjang 4 kali tinggi, dan lebar $6 \mathrm{~cm}$ lebih panjang dari tinggi. Apabila keliling alas balok adalah $42 \mathrm{~cm}$ dan panjang diagonal ruang adalah $25 \mathrm{~cm}$, tentukan volume balok? Periksalah kebenaran jawabanmu!

Kesalahan yang dilakukan siswa pada saat menyelesaikan masalah dianalisis dan ditampilkan salah satu perwakilan dari jawaban siswa yang mengalami kesalahan pada setiap tahapan.

\section{Analisis Kesalahan Jawaban Siswa pada Tahap Pemahaman}

Banyak siswa yang melakukan kesalahan pada tahap pemahaman adalah 5 orang. Berikut ini ditampilkan salah satu jawaban siswa yang salah pada tahap pemahaman sehingga memperoleh skor nol.

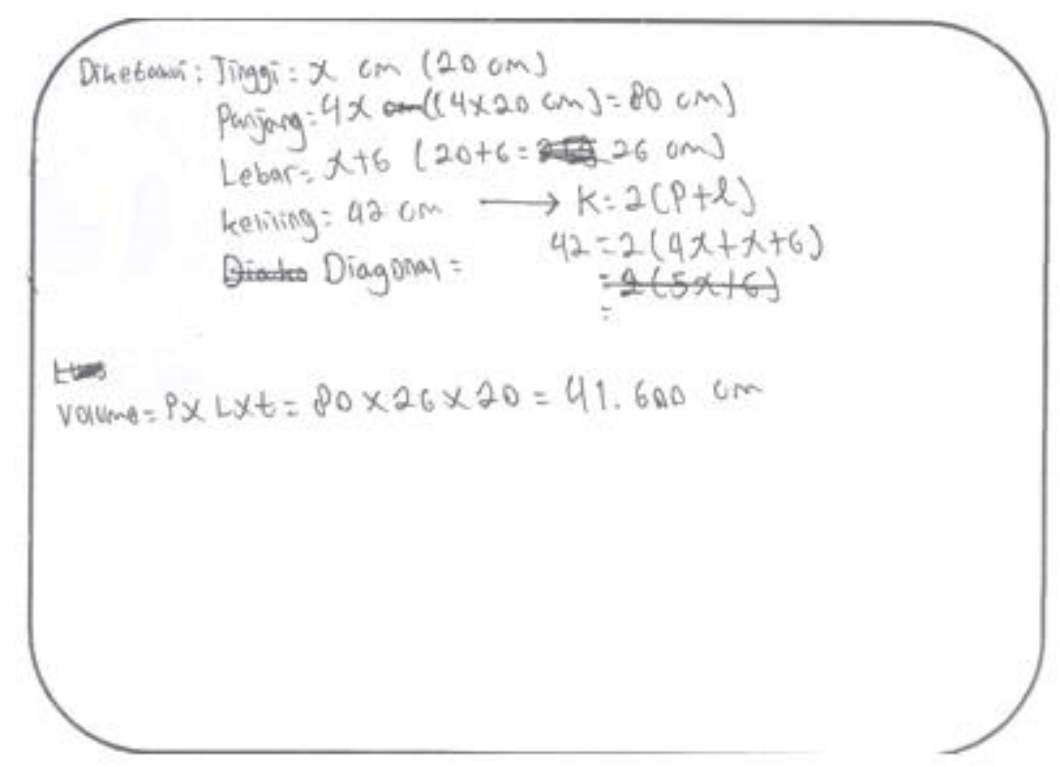

Gambar 1. Perwakilan Jawaban Siswa yang Salah pada Tahap Pemahaman

Pada Gambar 1 terlihat bahwa siswa sudah mengerti pertanyaan pada soal, tetapi belum memahami cara menyelesaikan soal. Siswa tidak dapat menentukan nilai $x$ dalam model matematika yang berbentuk persamaan aljabar. Siswa tidak dapat menjelaskan bagaimana memperoleh nilai $x=20 \mathrm{~cm}$.
Pada lembar jawaban siswa hanya menuliskan secara langsung bahwa nilai $x$ adalah 20 . Jawaban yang diberikan siswa tidak tepat.

Berdasarkan wawancara, siswa dapat mengerti maksud dari soal, tetapi mereka tidak paham cara menentukan nilai $x$ yang ditanyakan pada soal, sehingga mereka hanya 
menerka saja nilai $x$. Menurut angket diperoleh informasi bahwa siswa tidak menyenangi pelajaran matematika karena dianggap sulit untuk dipahami.

\section{Analisis Kesalahan Jawaban Siswa pada Tahap Transformasi}

Banyak siswa yang melakukan kesalahan pada tahap transformasi adalah 13 orang. Berikut ini ditampilkan salah satu jawaban siswa yang salah pada tahap transformasi sehingga memperoleh skor 1 .

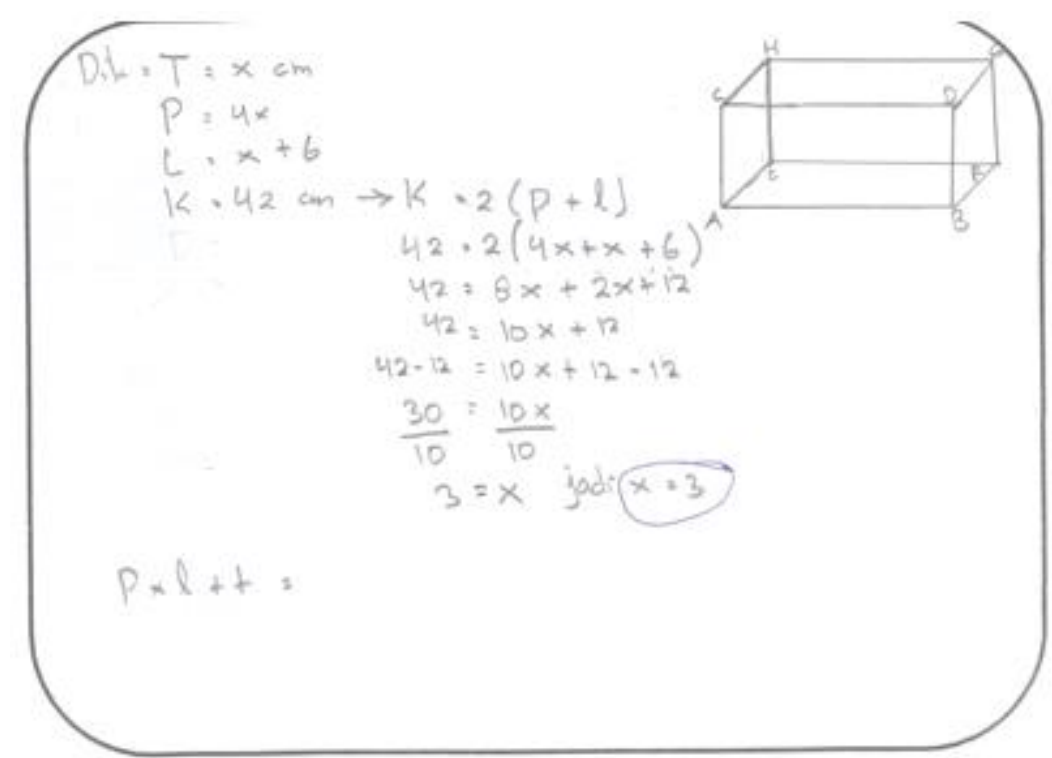

Gambar 2. Perwakilan Jawaban Siswa yang Salah pada Tahap Transformasi

Pada Gambar 2 terlihat bahwa siswa sudah mengerti dengan pertanyaan dan memahami cara menentukan nilai $x$ pada soal. Siswa memperoleh nilai $x=3$ melalui informasi keliling salah satu permukaan balok sama dengan $42 \mathrm{~cm}$. Setelah memperoleh nilai $x=3$, siswa melakukan kesalahan dalam mensubstitusikan nilai $x$ terhadap panjang dan lebar balok yaitu $4 x$ dan $x+6$. Kesalahan ini menyebabkan siswa tidak dapat memperoleh panjang dan lebar dari balok.

Berdasarkan wawancara, siswa memiliki kemampuan yang baik dalam operasi aljabar sehingga dapat menentukan nilai $x$. Kemudian siswa bingung yang mesti dilaku- kan berikutnya sehingga tidak melakukan substitusi nilai $x$ pada persamaan panjang dan lebar dari balok. Menurut angket, siswa tidak begitu menyenangi pelajaran matematika karena banyak konsep yang harus dipahami.

\section{Analisis Kesalahan Jawaban Siswa pada Tahap Keterampilan Proses}

Banyak siswa yang melakukan kesalahan pada tahap keterampilan proses adalah 29 orang. Berikut ini ditampilkan salah satu jawaban siswa yang salah pada tahap keterampilan proses sehingga memperoleh skor dua. 


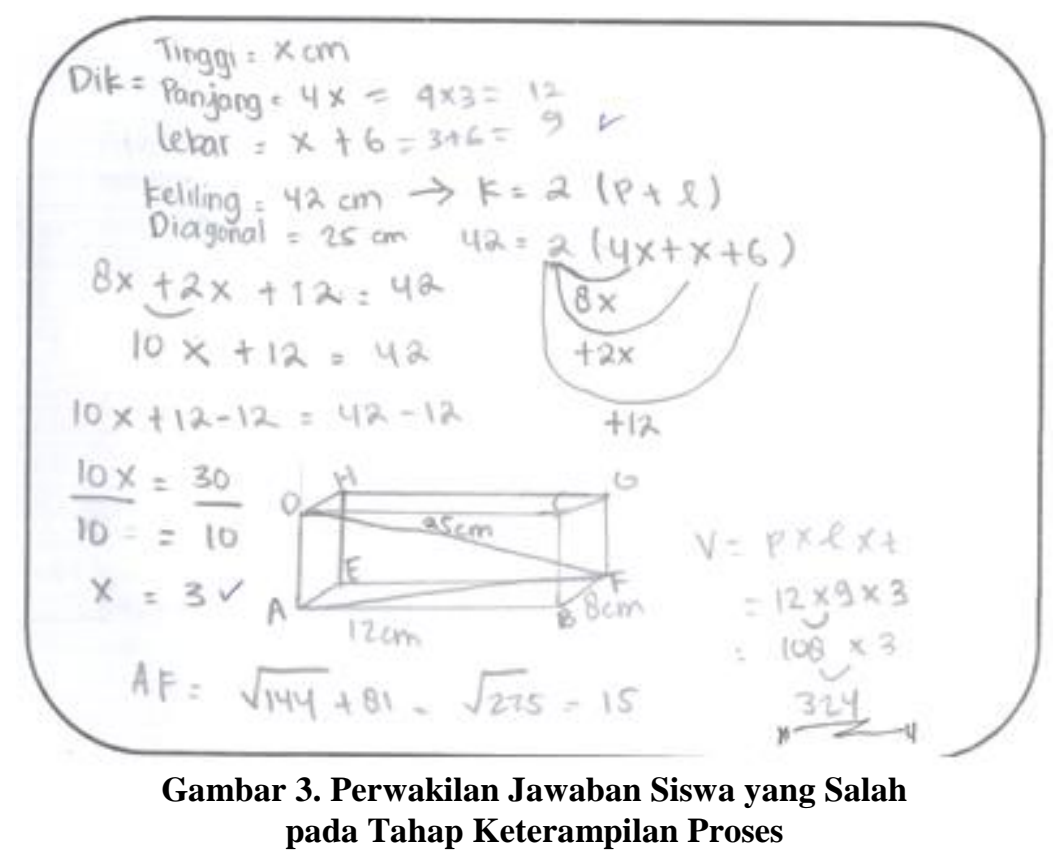

Pada Gambar 3 terlihat bahwa siswa sudah mengerti tentang pertanyaan pada soal. Siswa dapat memahami cara menentukan nilai $x$ melalui informasi keliling permukaan balok yang diketahui adalah $42 \mathrm{~cm}$. Siswa dapat melakukan operasi hitung dengan baik sehingga memperoleh nilai $x=3$. Siswa juga dapat melakukan transformasi nilai panjang dan lebar dengan mensubstitusikan nilai $x=3$ ke persamaan $4 x$ dan $x+6$ sehingga diperoleh panjang adalah $12 \mathrm{~cm}$ dan lebar balok adalah $9 \mathrm{~cm}$. Siswa memperoleh skor 2 karena dapat menentukan panjang dan lebar balok. Siswa tidak dapat menentukan panjang $A D$ yang merupakan tinggi balok $A B C D$.EFGH sehingga volume balok yang diperoleh tidak tepat.

Berdasarkan wawancara, siswa tidak mengalami kesulitan dalam menentukan nilai $x$ dan mensubstitusikan ke $4 x$ dan $x+6$ untuk memperoleh panjang dan lebar. Kemampuan dalam operasi hitung siswa juga baik. siswa juga dapat menggunakan teorema Pythagoras, tetapi siswa kesulitan menentukan tinggi balok karena bingung menentukan panjang diagonal ruang yang menjadi sisi terpanjang pada teorema Pythagoras.

Berdasarkan angket diperoleh informasi bahwa siswa kurang menyukai pelajaran matematika karena konsep yang ada pada matematika saling berkaitan, sehingga apabila tidak memahami satu konsep akan sulit memahami konsep selanjutnya. Siswa berusaha menjawab soal matematika karena tidak ingin memperoleh nilai rendah.

\section{Analisis Kesalahan Jawaban Siswa pada Tahap Penyimpulan}

Banyak siswa yang melakukan kesalahan pada tahap penyimpulan adalah 33 orang. Berikut ini ditampilkan salah satu jawaban siswa yang salah pada tahap penyimpulan sehingga memperoleh skor 3 . 


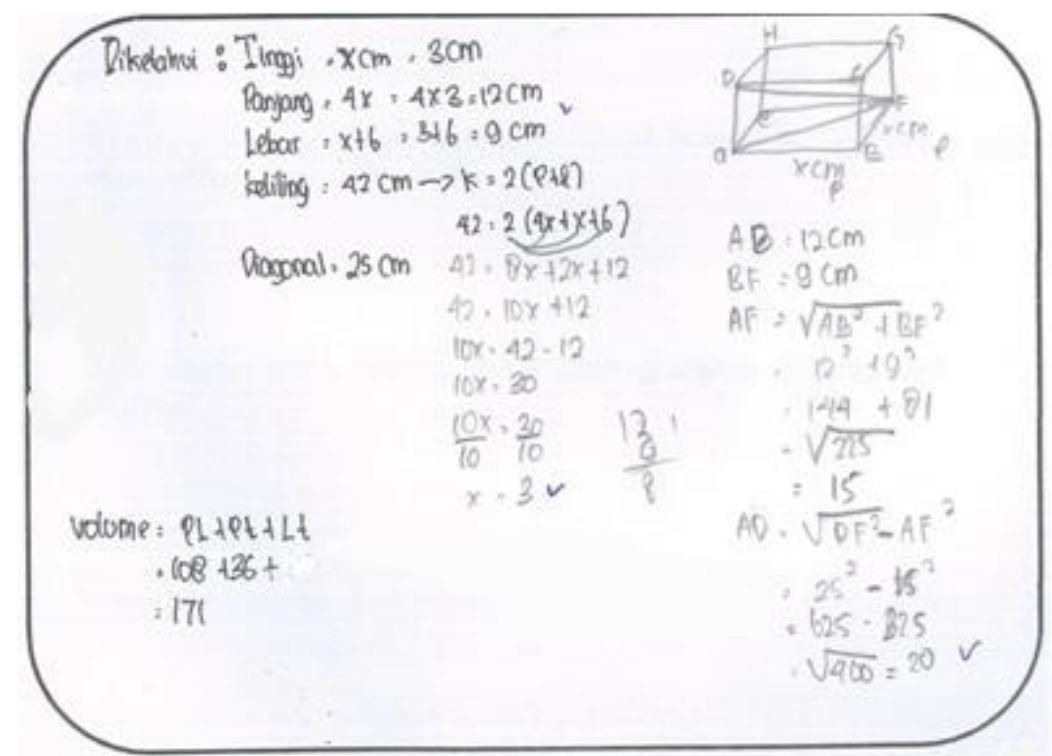

Gambar 4. Perwakilan Jawaban Siswa yang Salah pada Tahap Penyimpulan

Pada Gambar 4 terlihat bahwa siswa sudah memahami soal. Siswa dapat menentukan nilai $x=3$. Siswa juga dapat mensubstitusikan nilai $x=3$ ke persamaan $4 x$ dan $x+6$ sehingga diperoleh panjang balok adalah $12 \mathrm{~cm}$ dan lebar adalah $9 \mathrm{~cm}$. Siswa dapat mengkonstruksi bangun ruang balok dan menentukan tinggi $A D$. Melalui teorema Pythagoras siswa memperoleh nilai $\mathrm{AD}=20$ $\mathrm{cm}$ sehingga tinggi balok adalah $20 \mathrm{~cm}$. Siswa sudah dapat menentukan panjang, lebar, dan tinggi balok dengan benar. Namun, pada tahap penyimpulan untuk menentukan volume balok, siswa melakukan kesalahan. Siswa menulis volume balok $=p l+p t+l t$ semestinya volume balok $=p \times l \times t$. Siswa melakukan kesalahan pada tahap penyelesaian akhir dari soal sehingga memperoleh skor 3.

Berdasarkan wawancara, siswa tidak mengalami kesulitan dalam menentukan nilai $x$ melalui konsep keliling alas balok. Siswa memiliki kemampuan operasi hitung yang baik. Siswa dapat menerapkan teorema Pythagoras dengan benar. Kesalahan konsep volume disebabkan siswa tidak fokus sehingga konsep volume balok ditulis menjadi konsep luas permukaan balok. Berdasarkan angket, siswa menyenangi pelajaran matematika karena memberikan tantangan dalam menjawab soal. Meskipun membutuhkan konsentrasi tinggi agar terhindar dari kesalahan konsep.

Berdasarkan analisis terhadap kesalahan-kesalahan jawaban, sebagian besar siswa yang mengalami kesulitan dalam menyelesaikan soal disebabkan mereka tidak memahami materi tentang bangun ruang khususnya balok yang termuat dalam soal tersebut. Siswa juga tidak teliti dalam menyelesaikan soal karena ingin segera mengumpulkan tanpa memeriksa kembali jawaban. Siswa tidak menyukai pelajaran matematika karena menganggap bahwa pelajaran matematika itu sulit untuk dipahami.

Pada Tabel 2 berikut ini ditampilkan persentase pendapat siswa terhadap matematika.

Tabel 2. Persentase Pendapat Siswa terhadap Matematika

\begin{tabular}{|c|c|c|}
\hline \multirow{2}{*}{ Pernyataan Positif } & \multicolumn{2}{|c|}{ Persentase } \\
\hline & $\mathrm{Ya}$ & Tidak \\
\hline $\begin{array}{l}\text { Menyukai pelajaran } \\
\text { matematika. }\end{array}$ & 64,71 & 35,29 \\
\hline $\begin{array}{l}\text { Berusaha } \\
\text { menyelesaikan soal } \\
\text { matematika. }\end{array}$ & 76,47 & 23,53 \\
\hline $\begin{array}{l}\text { Merasa yakin dengan } \\
\text { jawaban. }\end{array}$ & 61,76 & 38,24 \\
\hline $\begin{array}{l}\text { Memiliki keinginan } \\
\text { mengerjakan soal } \\
\text { matematika. }\end{array}$ & 82,35 & 17,65 \\
\hline $\begin{array}{l}\text { Memeriksa kembali } \\
\text { jawaban. }\end{array}$ & 61,76 & 38,24 \\
\hline Rata-Rata & 69,41 & 30,59 \\
\hline
\end{tabular}




\begin{tabular}{lcc}
\hline \multirow{1}{*}{ Pernyataan Negatif } & Persentase & Persentase \\
\cline { 2 - 3 } & Ya & Ya \\
\hline $\begin{array}{l}\text { Sulit memahami materi } \\
\text { matematika. }\end{array}$ & 47,06 & 52,94 \\
$\begin{array}{l}\text { Merasa soal } \\
\text { matematika sulit. }\end{array}$ & 58,82 & 41,18 \\
$\begin{array}{l}\text { Tidak dapat menjawab } \\
\text { soal matematika. }\end{array}$ & 26,47 & 73,53 \\
$\begin{array}{l}\text { Mencontek jawaban } \\
\text { teman karena bingung } \\
\text { menyelesaikan soal } \\
\text { matematika. }\end{array}$ & 64,71 & 35,29 \\
\hline Rata-Rata & & \\
\hline
\end{tabular}

Pada Tabel 2 terlihat bahwa pada 34 siswa sebesar $69,41 \%$ memiliki pendapat yang positif terhadap matematika dan sebesar $49,27 \%$ siswa memiliki pendapat yang negatif terhadap matematika. Siswa sebanyak $64,71 \%$ menyukai pelajaran matematika. Ini menunjukkan bahwa lebih dari setengah siswa senang belajar matematika. Sejalan dengan penelitian (Putra, 2011) pada salah satu SMPN menunjukkan bahwa dari 36 siswa sebesar $85,93 \%$ memiliki sikap positif terhadap matematika.

Namun, hasil tes kemampuan pemecahan masalah matematis menunjukkan bahwa $97,06 \%$ siswa tidak dapat menyelesaikan soal, sehingga dapat dikatakan bahwa meskipun siswa menyukai pelajaran matematika, belum tentu mereka dapat menyelesaikan soal matematika dengan baik, karena untuk dapat menyelesaikan masalah matematika diperlukan ketelitian dan keterampilan daripada minat saja.

Berdasarkan Tabel 2 terlihat bahwa siswa sebanyak $58,82 \%$ merasa soal matematika sulit. Meskipun sulit, siswa sebanyak $76,47 \%$ berusaha menyelesaikan soal meskipun jawaban yang diberikan tidak tepat. Siswa yang merasa yakin dengan jawaban yang diberikan sebanyak 61,76\%. Namun, siswa masih mencontek jawaban teman karena bingung menyelesaikan soal sebanyak $64,71 \%$.

Data ini menunjukkan bahwa meskipun kemampuan pemecahan masalah siswa masih rendah, tetapi siswa memiliki pendapat yang positif terhadap matematika. Siswa tetap berusaha memberikan jawaban pada soal pemecahan masalah meskipun terasa sulit dan masih terdapat kesalahan.

\section{SIMPULAN}

Berdasarkan hasil penelitian yang dilakukan pada siswa kelas VII pada salah satu SMPN di Cimahi dapat disimpulkan bahwa kemampuan pemecahan masalah matematis siswa tersebut masih rendah. Dari 34 siswa hanya 1 orang yang dapat menyelesaikan soal dengan baik. Siswa tidak memahami masalah pada soal dialami sebanyak 5 orang. Siswa tidak dapat melakukan transformasi nilai $x$ pada persamaan matematika dialami sebanyak 13 orang. Siswa tidak memiliki keterampilan proses dalam menentukan tinggi balok dialami sebanyak 29 orang. Siswa tidak dapat menyimpulkan jawaban dalam menentukan volume balok dialami sebanyak 33 orang.

Siswa belum terbiasa mengerjakan soal-soal pemecahan masalah sehingga sulit memahami informasi pada soal. Siswa perlu dilatih mengerjakan soal-soal yang menuntut berpikir tingkat tinggi agar kemampuan pemecahan masalah matematis siswa dapat berkembang dengan baik. Meskipun siswa memiliki kemampuan pemecahan masalah matematika yang rendah, tetapi mereka memiliki pendapat yang positif terhadap matematika dengan rata-rata $69,41 \%$.

3-8). Reston, VA: National Council of Teachers of Mathematics.

Hadi, S., \& Radiyatul. (2014). Metode Pemecahan Masalah Menurut Polya untuk Mengembangkan Kemampuan 
Siswa dalam Pemecahan Masalah Matematis di Sekolah Menengah Pertama. Edu-Mat Jurnal Pendidikan Matematika, 2(1), 53-61.

Hendriana, H., \& Sumarmo, U. (2014). Penilaian Pembelajaran Matematika. Bandung: Reflika Aditama.

Mawaddah, S., \& Anisah, H. (2015). Kemampuan Pemecahan Masalah Matematis Siswa pada Pembelajaran Matematika dengan Menggunakan Model Pembelajaran Generatif (Generative Learning) di SMP. EduMat Jurnal Pendidikan Matematika, 3(2), 166-175.

Newman, M. A. (1977). An Analysis of Sixth-Grade Pupils' Error on Written Mathematical Task. Victorian Institute for Educational Research Bulletin, 39, 31-43.

Nurianti, E., Halini, \& Ijudin, R. (2015). Analisis Kesalahan Siswa dalam Menyelesaikan Soal Matematika Materi Pecahan Bentuk Aljabar di Kelas VIII SMP. Jurnal Pendidikan dan Pembelajaran, 4(9), 1-10.

Polya, G. (1973). How to Solve It: A New Aspect of Mathematical Method (2nd ed.). New Jersey: Princeton University Press.

Putra, H. D. (2011). Pembelajaran Geometri dengan Pendekatan SAVI Berbantuan Wingeom untuk Meningkatkan Ke- mampuan Analogi Matematis Siswa SMP. Seminar Nasional Pendidikan Matematika. 1, pp. 292-302. Cimahi: STKIP Siliwangi.

Putra, H. D. (2014). Tahap Perkembangan Kognitif Matematika Siswa MTs Asy Syifa Kelas IX Berdasarkan Teori Piaget. Prosiding Seminar Nasional Pendidikan Matematika. 2, pp. 224230. Cimahi: STKIP Siliwangi.

Ulvah, S. (2016). Kemampuan Pemecahan Masalah Matematis Siswa Ditinjau Melalui Model Pembelajaran SAVI dan Konvensional. Jurnal Riset Pendidikan, 2(2), 142-153.

Widodo, S., \& Kartikasari. (2017). Pembelajaran Pemecahan Masalah Matematis Siswa Sekolah Dasar dengan Model Creative Problem Solving (CPS). Jurnal Prisma Universitas Suryakencana, 6(1), 5765.

Winarni, E. S., \& Harmini. (2015). Matematika untuk PGSD (Keempat ed.). Bandung: Remaja Rosdakarya.

Windari, F., Dwina, F., \& Suherman. (2014). Meningkatkan Kemampuan Pemecahan Masalah Matematika Siswa Kelas VIII SMPN 8 Padang Tahun Pelajaran 2013/2014 dengan Menggunakan Strategi Pembelajaran Inkuiri. Jurnal Pendidikan Matematika, 3(2), 25-28. 